\title{
Language Politeness In Political Communication: Analysis of Leech's Politeness Principal on the Aceh Governor Candidate Debate in 2017
}

\author{
M. Akmal ${ }^{1}$ and Ratri Candrasari ${ }^{2}$ \\ \{akmal@unimal.ac.id ${ }^{1}$,ratri@unimal.ac.id ${ }^{2}$ \} \\ ${ }^{1}$ Department of Political Science, Universitas Malikussaleh, Aceh, Indonesia \\ ${ }^{2}$ Department of Agribusiness, Universitas Malikussaleh, Aceh, Indonesia
}

\begin{abstract}
This study aims to analyze the realization of linguistic politeness in political communication of governor candidates' debate. One form of current campaign is a candidate debate. The Independent Electoral Commission (KIP) in Aceh also began conducting the first candidate debate in the 2017 governor election. It is hoped that from the debate, the people can choose their prospective leaders more objectively by looking at their vision, mission, strategy, and policy through the debate. Furthermore, the community also assessed their attitude, behaviour and speech acts of the candidates pairs. Speech acts reflecting the use of the candidate's language, in other words language is one of the main means of politics. The study was conducted by analyzing the data of candidate pair debate in Aceh involving 6 candidate pairs competing in the 2017 election in Aceh province. The data were then analyzed based on Leech's linguistic principle. This research shows that there are some violations of linguistic politeness during the debate process. Linguistic politeness strategy should be a serious concern for candidate pairs in the upcoming campaign, because language in the political dimension is one powerful tool to gain and retain power.
\end{abstract}

Keywords: Linguistic politeness, Political communication, Leech's linguistic principles

\section{INTRODUCTION}

Political communication and linguistic politeness of politicians get the spotlight in an effort to communicate their vision of mission to society. How to communicate in terms of content and language when dealing directly with members of the community, especially in the the debate of Aceh governor candidates, is a great concern for public speaking. Candidate debate forum or candidate dialogue is one means to improve the quality of candidates, because in this forum the candidates will explain the background of nomination and the agenda that will be done if elected. The candidates can also convince the people with constructive and critical minds. Communities are free and democratic will know the agenda offered by the candidates. 
In addition to vision-mission, in a situation of inter-candidate competition, candidates must be able to create a good self-image. During the candidate debate forum, the candidate's self-image is not only seen from the gestures, but also from the speech. Candidates who can take care of themselves and the face of other candidates will get a good image in the eyes of the voting community. In the principle of language politeness, there is a concept of the face that explains that everyone has two faces or desires of the face / positive desire and face / negative desire. From the description, it is important to discuss how a language is used by politicians to maintain self-image by using language politeness strategies in political interaction

The Aceh Governor General Election 2017 has been done on February 15, 2017 and it has also been elected the Governor of Aceh period 2017-2022. The Independent Election Commission of Aceh passed 6 candidate pairs, with a composition of 3 pairs of independent candidates and 3 pairs of candidates from political parties. In contrast to other regions, the Aceh elections passed the presence of local parties, namely Partai Aceh (PA) and Partai Nasional Aceh (PNA) .The public debate was held three rounds, the first round was held on 22 December 2016 at Hermes hotel, Banda Aceh. the second was held on 11 January 2017 at Amel Convention Hall, in Aceh.The third debate was held on 31 January 2017 at Amel Convention Hall The three rounds of the debate were attended by 6 pairs of candidates for governor and vice governor.The Debate process was broadcasted both by local television channels and national television. Thus the entire people of Aceh both inside and outside of Aceh region could follow the course of the debate. Community can assess their future leaders not only in terms of intelligence, leadership, wisdom, but also in terms of politeness in both language in communicating and communicating ethics.

Politics and linguistic links are a phenomenon that politics is a speech (read: language) activity. Roelofs in his book "The Language of Modern Politics" states simply that "Politics is-talk, or rather politics is speaking" [1]. Politics is not just talk, but not all talk is politics. Politics certainly has its own ethics because basically it is the activity of people who manage their actions in a conflict of interests and goals. Every political setting is always marked by disputes and conflicts. On the other hand, language also has the power and dimension emancipotitic, transformative, and open in moral-ethical judgments. Language can be evil and bad especially when it is used as a means of manipulation and indoctination. Instead, language will be good when used as a means to improve human welfare. The phenomenon of language covers the field of socio-politics so that the phenomenon of language has a direct and significant impact on human political reality. Paletz and Lipinski [2] in their working paper states that it is indeed, in communications and political development, it is possible to analyze all social processes in terms of structure, contents, and flow of communication, because the flow of communications determines the direction and the pace of dynamic social development.

Media are now playing an active part in political field. Therefore, candidates of government leaders must be aware of this phenomenon since media can compose a societal institution for the political management of the public sphere and the media logic emerges. Kenterelidou [3] states that governments, in order to comply with the forenamed commitments and these newly coming trends, employ new communication policies and strategies. Furthermore, they set off modern publication, information, and tools such as "infoganda" (information and propaganda). Blumler [4] also stresses on the theories of communication in digital era, that there are a number of more freshly minted theories of voice, actors' roles, holistic and normative perspectives that are needed to be considered in doing public communication. 
This paper analyzes speech acts in the framework of the politeness of candidates of governors in their political communication during the candidate debate process. The analysis rests on the relationship of language and politics, the role and function of language as one means to obtain and maintain power. During the campaign period, politicians use certain slogans to convince people of their vision, mission and policy.

\section{THEORETICAL FRAMEWORK}

\subsection{Linguistic Politeness}

Linguistic / linguistic politeness is a pragmatic science study, which means that if one discusses linguistic politeness is to talk about pragmatics. The definition of politeness according KBBI is refinement and good language and behavior. Modesty is a behavioral rule that is established and agreed upon by a particular society so that politeness becomes a prerequisite of social behavior. Modesty is a cultural phenomenon, so it may be that what is considered polite by a culture may not be the case with other cultural groups.

The purpose of language politeness is to create a pleasant, effective, and non-threatening interaction atmosphere. Fraser [5] mentions that there are at least four views that are used to examine the problem politeness in speaking, namely: (1) The Social-Norm View. In this view, politeness in speaking is determined based on the norms that apply to a particular society. Santun dalan speak has a parallel meaning of language premises etiquette (language ettiquette); (2) Conversational Maxim and Face Saving. A view that sees politeness as a perfunctory maxim [pan and as an advance facial effort. A politeness view as a conversational maxim assumes the principle of politeness as merely a complement to the principle of cooperation; (3) Conversational Contrast. This view sees politeness as an action to fulfill the requirements of fulfillment of a conversation contract. So being polite is parallel to a thoughtful account; and (4) Sociolinguistic View. Modesty is seen as social indexing. Such social indices exist in forms of social, honorific, and speech references.

Meanwhile, according to Chaer \& Agustina [6] in general there are 3 rules that must be obeyed so that our speech sounds polite. The three areas are: (1) formality; (2) hesitancy; (3) and equality or camaraderie. It means that a speech is polite if it does not sound mamaksa or arrogant, giving speech choice of action to the opponent said, so the opponent said to be happy.

Good communication needs to consider the principles of language politeness as suggested by Leech [7][8]. He divided the theory of politeness into six maxim maxims: (1) Tact Maxim. The maxim of Tact dictates that every participant of the speech should minimize the loss of others, or maximize profit for others, (2) the maxim of Approbation requires the speaker to minimize self-gain and maximize his own loss, (3) Maxim of generousity. The maxim of generosity requires the speaker to minimize criticism against others, but must maximize praise to others, (4) the maxim of Modesty requires the speaker to minimize praise to himself, but must criticize himself as much as possible, (5) the maxim of Agreement requires one to maximizing agreements with others and minimizing disagreements with others and (6) maxim of Sympathy requiring speakers and spouses to maximize sympathy and minimize their sense of antipathy.

In addition to the above theories of politeness, Haugh [9] also suggests that politeness involves speakers' showing what they think about themselves and others, addressess' 
perceptions of those evaluations. Therefore, in this paper, try to reveal some utterances produced by the politicians to show what they think about themselves and others.

\subsection{Leech Politeness Model}

In Leech's politeness model, the scale of Leech's politeness is divided into five, namely:

1. Cost benefit scale or loss and profit scale, referring to the magnitude of the loss and profits caused by a speech act on a speech. The more the speech is detrimental to the speaker's self, the more polite it becomes. On the contrary, the more the speech profits the speaker's self, the more discouraged the speech becomes.

2. Optionality scale or scale of choice, pointing to the many or at least options (options) conveyed the speaker to the partner said in the activity speak. The more the speech allows the speaker or the spokesperson to make the choice of a lot and freely, will be regarded the more polite the utterance. Conversely, if the utterance does not at all give the possibility of choosing for the speaker and the speaking partner, the speech is considered to be impolite.

3. Indirectness scale refers to the direct or indirect rating of the meaning of a speech. The more such a direct utterance would be deemed the less polite it is. On the contrary, the more indirect, the purpose of a speech, will be regarded the more polite the utterance.

4. Authority scale refers to the relationship of social status between the speaker and the speech partner involved in the speech. The further the social rank (rank rating) between the speaker and the speech partner, the speech used will tend to be more polite. Conversely, the closer the social status rankings are between them, the tendency to decrease the degree of politeness of speech used in the speech.

5. Social distance scale refers to the rank of social relationships between speakers and speech partners involved in a speech. There is a tendency that the closer the social rank distance between the two, the less polite it will become. On the contrary, the further the social rank distance between the speaker and the speech partner, the more courteous the speech will be.

\subsection{Definition of Debate}

The term debate comes from English, synonymous with the Sawala language derived from the Kawi language which means holding fast to certain arguments in the strategy of arguing or arguing for salaing defeating or winning the tongue. So the definition of debate is a way of conveying ideas logically in the form of arguments with evidence supporting the case of each debating party.

In Indonesia there are two streams of debate, the first of which is the conventional flow and the second is the flow that follows international standards and is being used in Indonesia. In general, debates are conducted in groups. According to Dipodjojo [10], debate is an oral communication process expressed in language to defend opinions. Any debating party will argue, give a reason in a way that the opposing party argues or the other party who hears the debate becomes confident and in favor of it. While the speech dictionary Dictionary Indonesian (KBBI) debate is the discussion or exchange of opinions about a matter with give each other reasons to defend their opinions. 


\section{METHODS}

This research uses descriptive qualitative analysis where the researcher placed as main aspect. This research emphasizes the deep understanding aspect of a problem. The object of the study was the political debate session of Aceh governor candidate for gubernatorial candidate broadcasted by local tv and private tv. Language politeness in political debate sessions is reviewed comprehensively. Sources of data in this study is the recording of candidates for governor of Aceh in the first, second and third rounds. The first round was held on 22 December 2016 at Hermes hotel, Banda Aceh. The second round of debate was held on 11 January 2017 at Amel Convention Hall, in Aceh. The third debate was held on 31 January 2017 at the Amel Convention Hall.

The research instrument is an observation guideline that contains the maxim of Leech's language politeness with the choice of language politeness and violation of the principle of politeness of language. The scope of analysis are limited on the spoken sentences during the debate recorded and widely open in the www.youtube.com/watch2.

\section{Results and Discussions}

The result of the study consisted the subjects of 6 pairs of candidates or totaling 12 people all, the utterances taken from the first to the third round debate were 52 speeches that fit the principle of politeness with a percentage of $100 \%$. Principles of politeness in question include: (a) Tact Maxim of 4 speech or 7.6\%; (B) Generousity Maxim of 4 speeches or $7.6 \%$, (C) Approbation Maxim of 14 speeches or 26.9; (D) Modesty Maxim of 17 speeches or 32.9\%; (E) Agreement Maxim of 16 speeches or 30.76\%; and (F) Sympathy Maxim as much as 7 utterances or $13.46 \%$. All the politeness found in the description of the pairs' visions and missions. All of the candidates delivered their visions and missions in a proper and controlled way because their speech was mostly delivered by reading the prepared texts. The intonation and expressions are at accepted politeness.

However, after conducting a study of 52 selected speeches from the 12 Aceh governor candidates, several findings of a maximal courtesy violation were found. Here are some examples of maximal violations:

\subsection{Violation of Approbation Maxim:}

It contains a violation of the principle of language politeness at the maxim of Approbation because it has increased the loss of others and reduced the profit of others. The abuse of approbation maxim is demonstrated by speech that does not comply with simplicity, which is to reduce self-commendation, in other words the candidate doing maximum dispraises of others. The following is one of 9 violations found in this maxim.

Utterance: " Bikin JKA mudah, bikin anak lebih mudah, tapi Apa Karya ga bisa itu ... dan saya bisa.

(Making $J K A$ is easy, making children is easier, but Apa Karya cannot do it ... but I can) 


\subsection{Violation of Generousity Maxim}

It contains a violation of the principle of language politeness at the maxim of generousity. Almost all the candidates tried to humiliated the opponents by proposing questions about the oppenents' vision in the coming programmes but added closing sentences by asking some personal criticsm in the past government activities. It is violate this maxim because the spaker did not show the behaviour of giving generous appreciation to others to ask wise and "smart" question concerning the coming visions.

Utterance: " Bagaimana cara anda menyelesaikan poin poin MOU Helsinky dan turunan UUPA yang belum selesai. Sedangkan anda tidak bisa membuat kekompakan dangan DPRA dengan wakil gubernur dengan partai anda dahulu bahkan dengan kepala dinas yang sering anda gonta ganti"

(How do you complete the Helsinky MOU points and unfinished UUPA derivatives. While you can not make compactness with the DPRA, vice governor, and even with your party first even with the head of the service that you often mutually replace)

The reply of the oppenent also showed the same violation. The following is one of the examples:

Utterance: " ... Kemudian tadi saudara menyebut sebagai wakil guberbur. Saya itu boleh dikatakan bekerja sendiri. Satu tahun bekerja dengan saudara, kemudian habis itu putus tidak ada hubungan apapa. Jadi alasan sodara saya tidak memberikan jabatan itu salah besar. Jadi ada tugas gubernur anda wakil gubernur. Saudara bukan sopir saya, saudara adalah wakil gubernur saya ..."

(....then you mentioned as vice governor. It can be said that I worked alone. One year working with you, then finished, no relationship whatsoever. So the statement that I did not give the job was totally wrong. So there are the tasks for governor and vice governors. You were not my driver, you were my vice governor ...)

\subsection{Violation of Modesty Maxim}

This maxim tries to lead the speakers to appreaciate politeness in delivering speech. In public we have a written standard concensus that in a formal and official event, moreover if it is broadcasted nationally, the have to use a national language. But some candidates in the debates even spoke almos along the speech in local language. It is, of course, not considered as a proper behaviour since not all audiences and tv viewers can speak the local language.

The following is the question proposed by one of the candidates, "Bagaimana jika anda terpilih menjadi gubernur. Macam mana untuk membangun Aceh sedangkan anda todak memiliki DPRA satu persen pun ..." (What if you were elected as a governor, whereas you do not have even one percent of voice in DPRA..)

Utterance: " ...Lon nyo peugah bahasa Aceh sebab tanyo mandun ureng Aceh... Jade peu yang ata awak DPR nyan hana lagot. Na dua boh, phon berarti DPR ata diboh le DPR, ata diboh le rakyat, kedua independen ata ipeek le rakyat, menyo han keumah geupulang le rakyat, nyan lheh laju...."

(I speak now in Acehnese beacuse wea re all acehnese... So what DPR works did not work. There are 2 things, firsty DPR approved by DPR chosen by people, secondly independent. elected by people, so if they are not trusted anymore.. just recll them.... ) 
The recorded video showed that along the time given (5 minutes) in answering the question, the candidate used local language. Some viewers and even the floor felt uneasy when other audience bursted into tears laughing, while he or she did not understand the utterances of the candidates. As also revealed in the research entitled Politeness in CrossCultural Communication done by Huang (2008) that found what considered to be polite may not true according to other culture.

It is also found that at least three candidates showed to pay a little attention to the formality by using some local expression like Bek publoe Mie lam eumpang (don't buy a cat in a bag). In the earlier research done by Yasmeen et al (2014), it is observed that Pakistani politicians make the use of less formal and mixed language.

It was found that the most maxims violated by the candidates are at the three maxims, they are maxims of Approbation, maxim of generousity and maxim of modesty.

\section{Conclusions}

After conducting a review of the data obtained it can be concluded that most of the language decency violations committed by Aceh's candidate governors tend to violate the maxim of tact, maxim of generousity and maxim of modesty. This means that most of the candidates for governor in the candidate debate produce self-praise speeches, criticizing their political opponents by lowering the rewards. And the percentage of violations to the maxim of modesty is also very high, meaning many topics of discussion are not completed in the questioning, there is no conspiracy of view, but that there is self-defense and out of substance in question. There are several reasons so that speakers tend to try to violate the maxim of language decency in an effort to improve the excessive self-image, besides the governor candidates also tend to drop other candidates through his speech.

\section{References}

[1] H. M. Roelofs, The language of modern politics: an introduction to the study of government. Dorsey Press, 1967.

[2] D. L. Paletz and D. Lipinski, "Political culture and political communication," 1994.

[3] C. Kenterelidou, "Public Political Communication and Media. The case of contemporary Greece," Aristotle University, 2005.

[4] J. G. Blumler, "Core theories of political communication: Foundational and freshly minted," Commun. Theory, vol. 25, no. 4, pp. 426-438, 2015.

[5] B. Fraser, "Whither politeness," Pragmat. Beyond New Ser., vol. 139, p. 65, 2005.

[6] A. Chaer and L. Agustina, Kesantunan Berbahasa. Jakarta: Rineka Cipta, 2010.

[7] G. Leech, "Prinsip-prinsip pragmatik," Jakarta Univ. Indones., 1993.

[8] G. Leech, "The Pragmatics of Politeness,” J. Lang., vol. 91, no. 4, pp. 954-960, 2014.

[9] M. Haugh, "The discursive challenge to politeness research: An interactional alternative," $J$. Politeness Res. Lang. Behav. Cult., vol. 3, no. 2, pp. 295-317, 2007.

[10] A. S. Dipodjojo, “Komunikasi lisan,” Yogyakarta: Lukman, 1982. 